\title{
Perspectives of Using Internet on the Scientific Research among the Postgraduate Students at the University of Khartoum -Sudan
}

\author{
Esam Idress K. Al Hassan ${ }^{1, *}$ \\ ${ }^{1}$ Depatrment of Instructional Technology, Faculty of Education, University of Khartoum, Sudan \\ *Correspondence: Depatrment of Instructional Technology, Faculty of Education, University of Khartoum, \\ Omdurman, P.O. Box (406), Sudan. Tel: 249-914-005-281. E-mail: kamtoreidress@hotmail.com \\ Received: July 21, $2015 \quad$ Accepted: August 10, $2015 \quad$ Online Published: August 26, 2015 \\ doi:10.5430/wje.v5n5p11 URL: http://dx.doi.org/10.5430/wje.v5n5p11
}

\begin{abstract}
The purpose of this study was to identify the perspectives of using Internet on the scientific research among the Postgraduate Students at the University of Khartoum. The researcher used the descriptive analytical method, the population consisted of all Postgraduate students at the University of Khartoum (Master \& Ph.D.), registered during the year 2014. Of 3189 students; selected the stratified random sample totaling 441 students to represent four councils specialized in university, which represented $14 \%$ of the population. Five questions and two null hypotheses were formulated. The questionnaire was designed for data collection was analysed by using SPSS, following the appropriate statistical methods: Percentage, Arithmetic mean, Standard deviation, one group t-Test and ANOVA. A number of findings were reached the most important are: The Postgraduate students use the Internet largely as a principal source for research information; the first scientific Council is the Basic \& Engineering studies with average of (65.3), then Medical \& Health Studies, average (65), Humanities \& Educational Studies average (62.73), finally, Agricultural \& Veterinary Studies with average (61.75). Postgraduate students facing many obstacles when using the Internet for scientific research, including: Most references on the Internet in English langue, the possibility of penetration the scientific sites and e-mails and technical problems. No statistically significant differences to the Postgraduate students in the use of the Internet to collect information due to the type of registered degree".
\end{abstract}

Keywords: perspectives; postgraduate students; internet; scientific research; University of Khartoum

\section{Introduction}

The world witnesses, at present, an accelerated technological revolution in the field of information and communication, with the rapid development of information and communication technology (ICT) interaction patterns have change. Widespread use of instructional techniques such as Internet make life easier and serve several purpose such as education, communication, research and obtaining new information. Köroĝlu, (2012). Therefore instructional technology has been closely associated with (ICT), so any event in the instructional technology must be related to the development of the communication multiple means in the field of education.According to (Hussain, 2011) research and development have brought about world-wide technological revolution. From here distance learning is growing global industry in today's world, is available 24 hours a day. So people from anywhere in the world is venturing into online instruction to expand their knowledge and skills. (Corbett\&Brown, 2015).

Internet and its most used component WWW has turned into important source of information with widest coverage and the fastest access. It can be a great place to accomplish scientific research on many topics but finding quality web materials and using them in scientific research can be challenging.From here it becomes to use the Internet in a scientific research to adapt to the era of (ICT).

The Internet has changed the way that the universities deliver instruction libraries need to adapt and change because they are at the forefront of delivering access, services, and resources that meet the need of the distance students (Ellison, 2000). Also the Internet has become a preferred media for access to information, and increasingly finds a place in the lives of people (Tutgum \& et.al, 2011). It seems more important for Postgraduate student's category. 
It is obligatory for universities in developing countries to create all the possibilities to use the Internet to gather information for the undergraduate and postgraduate students and resolve whatever hinders these using for purpose in scientific research (UNESCO, 2002; Mason, 2000; Internet World Stats, 2014). By the other hand ,higher education in Sudan is witnessing significant development and progress on both quantitative and qualitative levels, not only has the increase in establishing public and private higher education institutions, but the improvement of qualitative performance of existing institutions and raising the components of their efficiency, by maximizing modern sources and technologies especially in scientific research. Therefore The Ministry of Higher Education and research in Sudan focused on research through supporting scientific research in public universities for Postgraduate, especially in the University of Khartoum, which is the first research university in the Sudan.

According to researcher, it does not find any evaluative study of the extent addressed the usage of graduate students in the Sudan of the Internet for the purposes of scientific research and how to take advantage of it to get the information. Hence, the importance of this study to determine the perspectives of Postgraduate students at the University of Khartoum to use the Internet for the purposes of scientific research and to get the scientific information.

Internet usage is spreading rapidly into daily life and it has an impact in many areas including the higher education systems (Thanuskodi, 2013). Saw the last three decades, tremendous developments in production techniques of sources information, either through on CD-ROM or by making them available across networks, and highlights from among those sources the information International network (Internet) because of its advantages in facilitating flow of information to postgraduate students.

The Internet has a unique potential to assist Postgraduate to develop the ability to build knowledge. Accessing the information easy, sharing the information and sources are important factors during this process. On the other hand, the university library accesses the Postgraduate students to achieve their scientific research and innovate new knowledge successfully. According to Khan \& Bhatti,2012), the university could not achieve its twin task of spreading knowledge and extending its research progress till it has provided itself to enrich library resources and services Included Internet.

The value of the Internet stems from its central role in information and communication technology with access to free online journals, magazines, and other information resources anytime and from anywhere for scientific research purposes (Kode \& Kode, 2003). Usun (2003) mentioned that Internet is appealing to higher education for a number of reason: it reduces the time lag between the production and utilization of knowledge; it promotes international co-operation and exchange of opinion; it further the sharing of information; and it promotes multidisciplinary research. As Daramola (2004) indicated that, an observable trend in the Internet is that more and more resources are moving to it and in some cases being made available only in the Internet.

Based of the above, can be take the advantage of the Internet in the field of instructional technology through organizing information, and delivering it to the learner and using as well as an educational tool, to include pictures, films and sound effects and visual which effective in the instructional process. (Alsharhan, 2007: 101). And also contributed significantly to the ease of research through downloading materials (Adegboji \& Toyo, 2006). When talking about the Internet and its utilization in education highlights the following question: Is the Internet a new fashion and fad of the present century fads can be used in education? Answered more than Educationalist: do not think that, this means it exists and increa singly used day after day.

Generally there are four main reasons to use the Internet in education which are the following:

(a) Internet is a realistic example for access the information from around the world

(b) Internet helps in collective and cooperative education, due to the increasing of information available online, it is too difficult for a student to research in all the menus, so you can use teamwork way among students where each student researching in a specific list and then students meet to discuss what has been reached.

(c) Helping Internet to contact with the world as soon as possible and less expensive.

(d) Internet helps to provide more than one way of teaching so the Internet is a large library where all the books are available, in additional there are some online educational programs for different levels (Moosa, 2006: 608). Therefore, the importance of Internet exactly in term of search in various sites for scientific researching and identifying the role will do in the development of research skills among Postgraduate students at the University of Khartoum, is an importance requirement for those interested in issues of higher education. 
However, little is known about the characteristics of the postgraduate students at the University of Khartoum toward using Internet on the scientific research, with this in mind, there is a need to assess Postgraduate student's perspectives toward using Internet and exploring factors relating to their uses of Internet in researches.

Although the value of the Internet as a receptacle of information, the way to get and interact with them is still one of the obstacles faced by Postgraduate students. The University of Khartoum has pursued approach aims to provide electronic data sources for various students specializations and access to use and interact with them, but it has not yet measure the students' interaction with them and their success and effectiveness in the development of the skill of collecting data for researchers from Postgraduate students. Which they are an important segment in need of such sources, and that the services offered by the library and the university in general and the electronic library in particular comes this study to identify the perspectives of using Internet on the scientific research among the Postgraduate students at the University of Khartoum, thus their opinions may provide an insight into the future usage of Internet to get information for scientific researching in higher education as generally.

\section{Objectives}

The main objectives of the study are, to:

1) Determine the extent of usage of postgraduate students at the University of Khartoum the Internet to get the research information.

2) Find out the role of the Internet, which can be contribute to the development of the research skills of the Postgraduate students at the University of Khartoum.

3) Identify the obstacles faced by the Postgraduate students at the University of Khartoum in usage of Internet to get information for scientific research.

\section{Questions}

The study sought to answer the following:

1) To what extent do Postgraduate students at the University of Khartoum usage the Internet to get information?

2) What are attitudes of Postgraduate students at the University of Khartoum to the role of Internet usage in the development of their research skills?

3) What are the main obstacles that behind Postgraduate students at the University of Khartoum for Internet usage to get information for scientific research?

4) How does degree registered impact on the extent of usage the Postgraduate students at the University of Khartoum the Internet?

5) How does type of the Scientific Council at the Faculty of Graduate Studies impact on the extent of usage the Postgraduate Students at the University of Khartoum the Internet?

\section{Hypotheses}

The study hypotheses are stated as:

1) There are no statistical significant differences between the perspectives of Postgraduate students at the University of Khartoum in the extent of usage the Internet due to the degree registered.

2) There are no statistical significant differences between the perspectives of Postgraduate students at the University of Khartoum in the extent of usage the Internet due to the type of the Scientific Council at the Faculty of Graduate Studies.

\section{Methods}

The researcher will depend on descriptive analytical method, was able to explore the participants perspectives on their behavior to the usage of Internet, and its role on the development of their research skills, which are based on the study Questions \& hypothesis. The study population consisted of graduate students at the University of Khartoum, master's and doctoral, of those registered during the year 2014, of the all complexes at University at Khartoum (Shambat, Center, Education, Medicine and Health Sciences Complex), according to the four scientific councils (Council of Medical and Health Studies, Council of Basic and Engineering studies, Council of Humanities and 
Educational Studies, Council of Agricultural and Veterinary Studies), that included all faculties in various specialization.

\subsection{Participants}

The participants of the study consisted of 441 students, were selected as a stratified random from all four scientific councils at the University of Khartoum, representing $14 \%$ of the population's (3149), table 1.

Table 1. Shows a Participants' Study

\begin{tabular}{lll}
\hline Council & Ph.D.'s Students & Master's Students \\
\hline Humanities and Educational Studies, & 34 & 148 \\
Agricultural and Veterinary Studies & 11 & 73 \\
Basic and Engineering studies & 11 & 64 \\
Medical and Health Studies & 17 & 83 \\
Number of registered students & 73 & 368 \\
\hline Total & & 441 \\
\hline
\end{tabular}

\subsection{Data Collection}

In order to collect data, using questionnaire was presented to arbitrators, through their comments and observations, were revised and restructuring some of the items. The final form of questionnaire is composed of three domains and (45) Statements.

To ensure reliability and validity coefficients of the, the questionnaire were distrusted to the pilot sample and by Using the method Asbierman and Brown \& alpha Cronbach respectively to determine the reliability coefficient of the final form of the questionnaire, which amounted (0.82) Accordingly, the coefficient of self-validity to be account, amounted (0.91), which is a good reliability and validity coefficients can be trusted.

\subsection{Data Analysis}

Researcher identified five options (Likert) for each domain, the first options were: very highly, highly, moderately, a low degree, do not use. While represented in the second and third domain options: Completely agree, Agree, Moderately agree, Disagree, Strongly Disagree, so given all grades $(5,4,3,2,1)$, respectively.

A total of 441 completed questionnaires out of 540 were obtained, this is $82 \%$ of respondents. Due to the descriptive nature of study, data collected through questionnaire were analyzed by using SPSS, following the appropriate statistical methods: Percentage, Arithmetic mean, Standard deviation, One group t-Test, One Way Anova.

\section{Results and Discussion}

Table 2 shows the responses of the respondents to the extent usage of Postgraduate students at the University of Khartoum the Internet to get information.

As a result, in table 2, 3 it is clear that all the 1st domain statements were statistically significant at the level of significance (0.05), where the mean average is equal to (54.388) which is higher than the Criterion - Value, which shows that there is a difference between the two means (values) for the benefit of a highly, which means that the usage of postgraduate students at the University of Khartoum to the Internet as essential source of information was very highly.

This result indicated that, the extend benefit of respondents of students at the faculty of Postgraduate studies at the University of Khartoum from global network in their assistance to get new information and interact with it. 
Table 2. The Extent Usage Internet to Get Information

Criterion - Value $=3 \quad$ Df $=440$

\begin{tabular}{|c|c|c|c|c|c|}
\hline No & Statements & Mean & Sd. & t- value & result \\
\hline 1 & I used Internet permanently in my study field. & 3.88 & 0.950 & 19.391 & Highly \\
\hline 2 & I agree to the usage of the Internet in my specialized field. & 4.29 & 0.866 & 31.177 & Very highly \\
\hline 3 & I can work without the Internet as a source of information. & 1.93 & 1.154 & -19.523 & Law \\
\hline 4 & $\begin{array}{l}\text { The utilization of Internet helps me to get as much } \\
\text { information }\end{array}$ & 4.31 & 0.973 & 28.328 & Very highly \\
\hline 5 & Refresh my information through the Internet. & 4.02 & 1.138 & 18.788 & Highly \\
\hline 6 & Internet makes me known all that is new in my study field. & 4.30 & & & Very highly \\
\hline 7 & $\begin{array}{l}\text { Internet facilitates me to contact with supervisor and } \\
\text { follow up my research. }\end{array}$ & 3.42 & 1.469 & 6.061 & Highly \\
\hline 8 & I used to communicate with my supervisor via e-mail. & 3.09 & 1.480 & 1.255 & moderately \\
\hline 9 & $\begin{array}{l}\text { Access to various sites on the Internet helps the use of the } \\
\text { scientific method of thinking }\end{array}$ & 3.78 & 1.262 & 12.905 & Highly \\
\hline 10 & $\begin{array}{l}\text { I prefer usage of the Internet to gather information related } \\
\text { with my research. }\end{array}$ & 3.59 & 1.266 & 9.783 & Highly \\
\hline 11 & $\begin{array}{l}\text { E-mail is used in communication more than other chat } \\
\text { programs. }\end{array}$ & 3.27 & 1.358 & 4.242 & moderately \\
\hline 12 & $\begin{array}{l}\text { Usage of the scientific sites in Internet, helping to improve } \\
\text { the researcher level in English language. }\end{array}$ & 3.94 & 1.148 & 17.126 & Highly \\
\hline 13 & Internet facilitates access to information in all areas. & 3.63 & 1.361 & 9.765 & Highly \\
\hline 14 & $\begin{array}{l}\text { Most faculties at the University of Khartoum are working } \\
\text { to expand the usage of the Internet base in all } \\
\text { specializations. }\end{array}$ & 3.45 & 1.371 & 6.877 & Highly \\
\hline 15 & $\begin{array}{l}\text { Information scientific specializations in Internet more than } \\
\text { information in literary specializations. }\end{array}$ & 3.50 & 1.354 & 7.739 & Highly \\
\hline
\end{tabular}

*Sig. at 0.05

Table 3. The Result of t- test (One Group) at First Domain "Extent Usage Internet to Get Information"

\begin{tabular}{lcccccc}
\hline \multicolumn{7}{c}{ Criterion - Value $=45$} \\
\hline Statements & Mean & \multicolumn{1}{c}{ Sd. } & t- value & Df & Sig.level at 0.05 & result \\
$1^{\text {st }}$ domain & 54.388 & 9.169 & 21.501 & 440 & Significant & highly \\
\hline
\end{tabular}

The result on the table 2, 3 shows that majority of the respondents were satisfied with their conduct and practice of usage the Internet to get information for the purposes of scientific research. As well as the working from most faculties at the University of Khartoum in order to expand the usage of the Internet base in all specializations. The result also showed some respondents were neutral on what to be contact with their supervisors by e-mail, statement 8 , and confirms that, what was reflected in the moderately result of statement 11 "E-mail is used in communication more than other chat programs". While referred to as a result of statement 3, where most of the respondents are not accustomed to work without the Internet as a source of information in order to obtain information for the purposes of scientific research. 
Table 4. The Attitudes of Respondents to the Role of Internet Usage in the Development of the Research Skills Criterion - Value $=3 \quad \mathrm{DF}=440$

\begin{tabular}{|c|c|c|c|c|c|}
\hline No. & Statements & Mean & Sd. & t-value & result \\
\hline 1 & $\begin{array}{l}\text { Internet helping to access into the international scientific } \\
\text { libraries. }\end{array}$ & 3.50 & 1.354 & 20.728 & Agree \\
\hline 2 & Internet saves time and effort, to get the information. & 4.06 & 1.073 & 33.950 & Agree \\
\hline 3 & Internet helps to enrich the researchers' knowledge. & 4.41 & 0.875 & 33.554 & Completely agree \\
\hline 4 & $\begin{array}{l}\text { Students have positive attitudes towards getting information } \\
\text { from the Internet. }\end{array}$ & 4.41 & 0.886 & 25.640 & Completely agree \\
\hline 5 & $\begin{array}{l}\text { I am looking for information on the Internet depending on } \\
\text { myself without technical support. }\end{array}$ & 4.15 & 0.942 & 21.417 & Agree \\
\hline 6 & $\begin{array}{l}\text { Access of information becomes even more pleasure by using } \\
\text { the Internet. }\end{array}$ & 4.11 & 1.085 & 22.811 & Agree \\
\hline 7 & $\begin{array}{l}\text { Internet contributes to the development of the Postgraduate } \\
\text { student's skill in information collection. }\end{array}$ & 4.15 & 1.060 & 25.420 & Agree \\
\hline 8 & $\begin{array}{l}\text { Internet contributes to the connection of postgraduate } \\
\text { students with their peers. }\end{array}$ & 4.21 & 1.002 & 28.195 & Completely agree \\
\hline 9 & $\begin{array}{l}\text { Internet helps postgraduate students to know and take } \\
\text { advantage of research and information centers. }\end{array}$ & 4.23 & 0.914 & 27.610 & Completely agree \\
\hline 10 & $\begin{array}{l}\text { Internet encourages postgraduate students to look over } \\
\text { scientific journals relevant to their study field. }\end{array}$ & 4.24 & 0.945 & 29.848 & Completely agree \\
\hline 11 & $\begin{array}{l}\text { The possibility of finding guides of scientific sites and } \\
\text { providing postgraduate students out. }\end{array}$ & 4.24 & 0.876 & 31.032 & Completely agree \\
\hline 12 & $\begin{array}{l}\text { Internet contributes to promote the exchange of ideas } \\
\text { between postgraduate students in various universities. }\end{array}$ & 4.25 & 0.846 & 27.672 & Completely agree \\
\hline 13 & $\begin{array}{l}\text { Internet provides the means of cooperation and dialogue } \\
\text { between researchers from different countries. }\end{array}$ & 4.17 & 0.886 & 28.775 & Agree \\
\hline 14 & $\begin{array}{l}\text { Internet contributes to the promotion of postgraduate } \\
\text { student's skill in collection information through } \\
\text { communication with his teachers. }\end{array}$ & 3.45 & 1.371 & 35.292 & Agree \\
\hline 15 & $\begin{array}{l}\text { The diversity of scientific sites led to improve of Postgraduate } \\
\text { student's skill in collection. }\end{array}$ & 3.50 & 1.354 & 38.594 & Agree \\
\hline
\end{tabular}

*Sig. at 0.05

Table 5. The Result of T- Test (One Group) at Second Domain "Attitudes of Respondents to the Role of Internet Usage in the Development of the research Skills"

\begin{tabular}{|c|c|c|c|c|c|c|}
\hline \multicolumn{7}{|c|}{ Criterion - Value $=45$} \\
\hline Statements & Mean & Sd. & t- value & Df & Sig. level at 0.05 & Result \\
\hline $2^{\text {nd }} \quad$ domain & 63.494 & 7.868 & 49.364 & 440 & Significant & Agree \\
\hline
\end{tabular}

According to the results in tables 4, 5: about attitudes of respondents to the role of Internet usage in the development of the research skills, the all $2^{\text {nd }}$ domain statements were statistically significant at the level of significance (0.05), where the mean average is equal to (63.494) which is higher than the Criterion - Value, this result explains that there is a difference between the two means (values) for the benefit of a "Agree", the findings indicated that the majority of the respondents expressed favorable attitudes to the role of Internet usage in the development of the research skills, this result with agreed the study of Asan \&Koca (2006) and Peng \& Wu (2006). Which means that the approval from the postgraduate students at the University of Khartoum of the role played by the global information network (Internet) in the development of their scientific research skills (skill of collection information). Particularly, students were more agree on: getting information from the Internet; Internet helping to enrich the researchers' knowledge; knowing and taking advantage of research and information centers; Internet contributes to the connection of postgraduate students with their peers; to promote the exchange of ideas between Postgraduate students in various universities; Internet encourages to look over scientific journals; and the possibility of finding guides of scientific sites and providing Postgraduate students out. 
Table 6. The Obstacles That Behind Respondents to Get Information for Scientific Research

Criterion - Value $=3$

$\mathrm{Df}=440$

\begin{tabular}{|c|c|c|c|c|c|}
\hline No. & Statements & Mean & Sd. & t-value & result \\
\hline 1 & $\begin{array}{l}\text { A technical problems when usage the World Wide Web } \\
\text { (Internet) to get information. }\end{array}$ & 3.50 & 1.238 & 8.540 & Agree \\
\hline 2 & $\begin{array}{l}\text { It is difficult to deal with the Internet to get the } \\
\text { information, that need to the specialist technical. }\end{array}$ & 2.90 & 1.317 & -1.663 & Moderately agree \\
\hline 3 & Internet does not give the required information directly. & 2.85 & 1.265 & -2.484 & Moderately agree \\
\hline 4 & The cost of Internet usage is still high. & 2.80 & 1.241 & -3.338 & Moderately agree \\
\hline 5 & $\begin{array}{l}\text { Confidence Lack in the effectiveness usage of Internet to } \\
\text { get information. }\end{array}$ & 2.78 & 1.171 & -3.905 & Moderately agree \\
\hline 6 & $\begin{array}{l}\text { Difficult to keep up with the rapid development of the } \\
\text { Internet and computer techniques programs. }\end{array}$ & 2.90 & 1.313 & -1.559 & Moderately agree \\
\hline 7 & Usage of Internet has led to reduction of the books value. & 3.27 & 1.405 & 3.967 & Moderately agree \\
\hline 8 & More scientific references on the Internet in English. & 3.70 & 1.242 & 11.849 & Agree \\
\hline 9 & $\begin{array}{l}\text { The difficulty of access to information because of the large } \\
\text { number of Web pages on the Internet. }\end{array}$ & 3.19 & 1.304 & 3.103 & Moderately agree \\
\hline 10 & $\begin{array}{l}\text { Lack scientific accuracy of much information on the } \\
\text { Internet. }\end{array}$ & 3.01 & 1.223 & 0.156 & Moderately agree \\
\hline 11 & $\begin{array}{l}\text { Multiple search engines makes you spend more time in the } \\
\text { search for information. }\end{array}$ & 2.89 & 1.306 & -1.750 & Moderately agree \\
\hline 12 & $\begin{array}{l}\text { Instability of some scientific sites, that information taken } \\
\text { from them. }\end{array}$ & 3.26 & 1.156 & 4.780 & Moderately agree \\
\hline 13 & $\begin{array}{l}\text { The lack of sufficient number of computers with internet } \\
\text { services in electronic libraries }\end{array}$ & 3.69 & 1.173 & 12.420 & Agree \\
\hline 14 & $\begin{array}{l}\text { Paper references are still the mainly for access to } \\
\text { information in scientific research. }\end{array}$ & 3.57 & 1.302 & 9.253 & Agree \\
\hline 15 & $\begin{array}{l}\text { Electronic libraries are not prepare, to help the } \\
\text { Postgraduate students on systematic research about } \\
\text { information }\end{array}$ & 3.69 & 1.170 & 12.372 & Agree \\
\hline
\end{tabular}

*Sig. at 0.05

Table 7. The Result of $\mathrm{t}$ - Test (One Group) at $3^{\text {rd }}$ Domain "Obstacles that Behind Respondents for Internet Usage to Get Information for Scientific Research

\begin{tabular}{|c|c|c|c|c|c|c|}
\hline \multirow[b]{2}{*}{ Statements } & \multicolumn{3}{|c|}{ Criterion - Value $=45$} & \multirow{2}{*}{$"$ Df } & \multirow[b]{2}{*}{$\begin{array}{c}\text { Sig. level at } \\
0.05 \\
\end{array}$} & \multirow[b]{2}{*}{ result } \\
\hline & Mean & Sd. & t- value & & & \\
\hline $3^{\text {rd }}$ domain & 48.016 & 9.945 & 6.368 & 440 & Significant & Agree \\
\hline
\end{tabular}

As a result, in Table 6,7 it shows that the $3^{\text {rd }}$ domain statements about the Obstacles behind the respondents for Internet usage to get information for scientific research are statistically significant at the level of significance (0.05), where the mean average is (48.016) which is higher than the Criterion - Value, which indicates that there is a difference between the two means (values) for the benefit of a "Agree". The findings explained that, the majority of Postgraduate students at the University of Khartoum faced several obstacles while using the Internet for the purposes of scientific research, mainly: Most references on the Internet in English langue; Electronic libraries are not prepare, to help the Postgraduate students on systematic research about information; lack of sufficient number of computers in electronic libraries; paper references are still the mainly for access to information in scientific research; addition a technical problems when usage the World Wide Web to get information.

There are some statements show that the respondents have expressed unsatisfied about them, where the result is" Moderately agree". This result indicated that the Postgraduate students at University of Khartoum of respondents were not sure for example, the following as an obstacle: Extent an instability of some scientific sites that information gotten from them, the usage of Internet can lead to a reduction of the books value, difficulty of access to information for, of the large number of Web pages on the Internet in addition to, the Lack of scientific accuracy of much information on the Internet. 
Bases on this result, can be said that current electronic libraries status that dedicated to Postgraduate students at University of Khartoum does not cover the main purpose of which is to provide information for Postgraduate students that are looking for in their study field which made the burden on the student to search randomly for these information in different locations. See statements 13, 15.

To answer the fourth question "How does degree registered impact on the extent of usage the Postgraduate students at the University of Khartoum the Internet"? And check with the first hypothesis: "There are no statistical significant differences between the perspectives of Postgraduate students at the University of Khartoum in the extent of usage the Internet due to the degree registered ". Associated with, it has been applied (T) test for the average two independent groups to know sign of the differences between the sample who registered $\mathrm{PhD}$ and their colleagues registered for a master's degree with regard to their use of the Internet. Table (8) shows the result.

Table 8. Shows the Result of (T) Test between Postgra Duate Students (PhD \&master) to Their Use of the Internet

\begin{tabular}{lllllll}
\hline $\begin{array}{c}\text { Comparison of two } \\
\text { groups }\end{array}$ & Mean & Sd. & t- value & Df & $\begin{array}{c}\text { Prob. } \\
\text { value }\end{array}$ & Sig. level at $\mathbf{0 ~ . 0 5}$ \\
\hline $\mathrm{MA}$ & 45.622 & 8.408. & 1.323 & 439 & 0.186 & \\
$\mathrm{PhD}$ & 53.029 & 12.653 & & & & No significant \\
\hline
\end{tabular}

Table 8 above shows that the value of (T) calculated equal to (1.323) with degree of $\mathrm{Df}(439)$ and Probability value (0.186), indicating that there were no statistically significant differences at the level of significance (05.0) regarding the usage of Postgraduate students at the University of Khartoum the Internet depending on the type of degree (MSc / $\mathrm{PhD}$ ) On the basis of this results given in table 8 the 1St hypothesis that: "There are no statistical significant differences between the perspectives of Postgraduate Students at the University of Khartoum in the extent of usage the Internet due to the degree registered" was accepted.

The lack of significant differences between graduate students at the University of Khartoum regarding the use of the Internet for the purposes of scientific research due to the type of degree, may be an unexpected result from the viewpoint of the researcher, this is matter probably needed for further studies thus, are not available any studies have reached this result.

To answer the five question "How does type of the Scientific Council at the Faculty of Graduate Studies impact on the extent of usage the Postgraduate students at the University of Khartoum the Internet? And check with the $2^{\text {nd }}$ hypothesis" There are no statistical significant differences between the perspectives of Postgraduate students at the University of Khartoum in the extent of usage the Internet due to the type of the Scientific Council at the Faculty of Graduate Studies". Associated with, it has been applied (F) test to know sign of the differences between the samples of Postgraduate Students of usage the Internet due to the type of the Scientific Council at the Faculty of Graduate Studies. Table 9 shows the result.

Table 9. Shows the Result of (F) Test between the Postgraduate Students of Usage the Internet due to the type of the Scientific Council at the Faculty of Graduate Studies

\begin{tabular}{lcccccc}
\hline $\begin{array}{c}\text { Comparison of two groups: } \\
\text { Scientific Councils at the Faculty } \\
\text { of Graduate Studies }\end{array}$ & Mean & Sd. & N. & F. value & $\begin{array}{c}\text { Probability } \\
\text { value }\end{array}$ & $\begin{array}{c}\text { Sig. level at } \\
\mathbf{0 ~ . 0 5}\end{array}$ \\
\hline Humanities \& Educational Studies & 62.738 & 7.652 & 187 & & & \\
Basic \& Engineering studies & .5 .342 & 7.243 & 79 & & & Significant \\
Medical \& Health Studies & 65.011 & 6.097 & 92 & 4.62 & 0.03 & \\
Agricultural \& Veterinary Studies & 61.759 & 9.896 & 83 & & & \\
\hline
\end{tabular}

The table 9 Shows that, there are presence of statistical significance equal to $(0.03)$ for the value of $F(4.625)$, which means that there is a statistically significant difference at the level of significance $(0.05)$ between the perspectives of Postgraduate Students at the University of Khartoum in the extent of usage the Internet due to the type of the Scientific Council at the Faculty of Graduate Studies, which Indicating a rejection of the $2^{\text {nd }}$ hypothesis. This result revealed that the views of Postgraduate students in the scientific councils differ in their usage of the Internet in the development of scientific research skills, for the benefit of the Basic\& engineering studies Council then the Council of Medical \& Health Studies, then comes Humanities \& educational studies Council and finally the Council of Agricultural \&Veterinary Studies. 
These results supported by the study of Mohammad and Alkaraki (2008) referred that previous studies related to Internet usage revealed: There are significant relationships between the Internet attitudes and field of studies. And agreed with the study of (Ali, 2003) and (Awad Karim, 2009) that the usage of the Internet as a source of information in the fields of science more widely used than in other fields.

On the other hand, the result showed that the Council of Agricultural \& Veterinary studies comes in last place; I believe that this is due to the student's adoption of agricultural and veterinary studies on laboratory experiments to obtain the results and information that they need in their research with their use of Internet as a source of information.

In general, Postgraduate students showed positive perspectives toward the role of Internet usage in the development of their research skills. The overall positive attitudes could be attributed to the availability and accessibility to computers and Internet that given to postgraduate students at the University of Khartoum.

\section{Conclusion}

Khartoum University has expanded over the last decade to provide electronic information sources for Postgraduate students through the availability of the global network of information services (Internet) in different forms and for all specializations, but it is not yet to measure its success and effectiveness extent in development of the skill of the information collection among Postgraduate students. From here, this attempt comes to find out the perspectives of using Internet on the scientific research among the Postgraduate Students at the University of Khartoum.

The findings of this paper show that the Postgraduate students in the four scientific councils of University of Khartoum usage the Internet largely as a principal source for information research, the first scientific Council is the basic engineering with average of (65.3), the Council of Medical and Health Studies, average (65), and the Council of Humanities and Educational average (62.73). Finally, the Board of Studies of agricultural and veterinary, average (61.75). The Internet would help significantly to the development of the skill of collecting research information among Postgraduate students. Further, results indicate no statistically significant differences to the Postgraduate students at the University of Khartoum in the usage of the Internet to due to the type of registered degree" Master$\mathrm{PhD}$. This is expected, as the Postgraduate students and their usage of Internet would have been related to the fulfillment of their research tasks.

In order to attain improvements in the research's Postgraduate, the decision -maker in faculty studies have to consider the fit between the tasks requirements and the functions abilities of their Internet. When there is a fit, this would create a positive perception among the Postgraduate in term of the usefulness and satisfaction of their Internet systems and therefore, promote best level for usage Internet in their scientific research.

However, it is obvious that Postgraduate students at the University of Khartoum need to do more in order to improve on their skills so as to equip them in utilizing the enormous benefits available in electronic formats, This is also as a result of their perception of ease and usefulness of electronic sources such as the Internet.

\section{Acknowledgements}

The researcher would like to gratefully acknowledgements to the Deanship of the Graduate College at the University of Khartoum for his moral and material support, and to Postgraduate students at the University of Khartoum who willingly accepted to be part of the research samples .I would also like to thank the arbitrators of the questionnaire for their observations and comments.

\section{References}

Adegboji, O.B., \& Toyo, O.D. (2006). The impact of the Internet on research: The experience of Delta State University, Abraka, Nigeria. Library Philosophy \& Practice, 8(2), 1-8

Al Sharhan, G. (2007). Instructional Media \& developments in instructional technology. Riyadh: Alkhmasi presses.

Ali, J. (2003). The using of Internet in scientific research. Master dissertation, University of Azhari, Faculty of Education, Khartoum.

Asan, A., \& Koca, N. (2006). An analysis of students ' attitudes towards Internet. Forth International Conference on Multimedia and Information and Communications Technologiines in Education, Seville, Spain. Retrieved from http://w w w.formatex.org/micte2006/pdf/2120-2124.pdf 
Awad Karim, A. (2009). Usage of Internet at the faculties of medical at the University of Azhari and Khartoum Faculty of Medical Sciences. Master dissertation, University of Azhari, Faculty of Education, Khartoum.

Corbett, A., \& Brown, A. (2015). Online Journal of Distance Learning Administration, 18(2). University of West Georgia, Distance Education Center. Retrieved http://www.westga.edu/ distance/ojdla/summer182/corbett_brown182.html

Daramola, I.S. (2004). Knowledge and skills possessed by technical collage graduate of building technology trade in Taraba State. Journal League of Researchers in Nigeria, 4(1).

Ellison, J. (2000). Distance Learning for today's Librarian. Limrary review, 49(5), 240-242. http://dx.doi.org/10.1108/00242530010331763

Hussain, I. (2011). Role of Internet technology in promotion research attitude among university academic. "World Conference of Educational Technology Researches".Organized by the Middle East University of North Cyprus, July 4-7.

Internet World Stats (2014). Retrieved from http://www.Internetworldstats.com/africa.htm\#ng

Kham, A., \& Bhatti, R, (2012). Department libraries at the university of Peshawer.Curent status, Services, Issues, Challenges and Prospects. Retrieved from http://www.digitalcommons.unl.edu/libphilprae/860

Kode, S., \& Kode, A. (2003). Free online serials in the area of library and Information Science. Annals of library and Information Studies, 50(4), 146-152.

Köroĝlu, O. (2012). New Media in Term of Human Computer Interaction. AJIT-e Online Academic Journal of Information Technology, 3(6), 7-26. http://dx.doi.org/10.5824/1309-1581.2012.1.001.x

Mason, R. (2000). From Distance Education to online Education. The Internet and Higher Education, 3(1-2), 63-74. http://dx.doi.org/10.1016/S1096-7516(00)00033-6

Mohammed. J., \& Al-karaki, J. (2008). Integrating Internet into traditional education: A practical study of university students' usage and attitudes. International Arab Journal of Information Technology, 5(3), 45-63.

Moosa, A. (2006). Introduction to Computers \& Internet. Riyadh: King Fahd National Library.

Peng, Tasi, C., \& Wu, Y. (2006). University students' self-efficacy and their attitudes towards the Internet: The role of students' perceptions of the Internet. Educational Studies, 32, 73-86. http://dx.doi.org/10.1080/03055690500416025

Thanuskkodi, S. (2013). Gender Differences in Internet Usage among College Students: A comparative Study. Library Philosophy and Practice (e-journal). Retrieved from http://wwwdigitalcommons.unl.edu/liphilprac/1052

Tutgum, A., Deniz, L., \& Moon, Man-Ki. (2011). A comparative Study of Problematic Internet Use and Loneliness among Turkish and korian Prospective Teachers. The Turkish Online Journal of Educational Technology (TOJET), 10(4), 14-30.

UNESCO (2002).Open and Distance Learning Trends. Policy and Strategy Considerations. Paris.

Usun, S. (2003). Undergraduate student's attitudes towards educational uses of Internet. Interactive Educational Multimedia. Retrieved from http://www.ub.edu/multimedia/item/down/c7/IEM_number7.pdf 